\title{
Effects of drought on the induced defence reaction of Scots pine to bark beetle-associated fungi
}

\author{
L Croisé, F Lieutier \\ INRA, Station de Zoologie Forestière, Ardon, 45160 Olivet, France
}

(Received 3 April 1992; accepted 14 September 1992)

\begin{abstract}
Summary - Water stress was imposed on Scots pine saplings grown in a greenhouse. Predawn leaf water potential $\left(\psi_{\mathrm{wD}}\right)$ was monitored regularly while carbohydrate reserves were quantified in the phloem, xylem and shoots. Trees were inoculated in the bole with a bark beetle-associated fungus at 4 different periods of the year; the induced defence reaction was quantified 2-3 wk later by its length and the total amount of resin. A decrease in the induced reaction (length and resin quantity) was observed in the most severely stressed trees. However, no clear relationship could be established between the concentration of carbohydrates (soluble or hydrolysable) and the intensity of the defence reaction.
\end{abstract}

pinus sylvestris / phytopathogenic fungus / induced defence reaction / water stress / predawn leaf water potential / carbohydrate reserve

Résumé - Action d'un stress hydrique sur la réaction de défense induite du pin sylvestre contre des champignons issus d'insectes Scolytides. Un stress hydrique a été appliqué en serre sur des pins sylvestres de 6 ans. Des champignons phytopathogènes préalablement isolés d'insectes Scolytides ont été directement inoculés dans le liber de ces arbres afin de préciser l'effet de la contrainte hydrique sur les caractéristiques de la réaction locale de défense (longueur et quantité totale de résine). L'état hydrique des arbres a été suivi régulièrement par des mesures du potentiel hydrique de base au niveau des aiguilles $\left(\psi_{w D}\right)$. Les réserves glucidiques de l'arbre ont été dosées dans le liber, l'aubier et les pousses au moment des inoculations. Quatre séries d'expérience ont ainsi été réalisées sur les mèmes arbres, de mai à octobre 1989. Pour des potentiels de base allant jusqu'à $-2 \mathrm{MPa}, \psi_{w D}$ est systématiquement et négativement corrélé avec les caractéristiques de la réaction de défense dans chaque série d'expériences (tableau I). Aucune différence concernant la teneur en glucides n'apparaît entre les arbres stressés et les témoins dans les différents compartiments considérés (tableau II).

Pinus sylvestris / champignon phytopathogène / réaction de défense induite / stress hydrique /potentiel hydrique foliaire / réserve glucidique 


\section{INTRODUCTION}

In coniferous trees attacked by bark beetles, an induced reaction visible as a resinous impregnation of the tissues surrounding the point of aggression plays a determining role in the resistance of the tree. In the majority of cases, the reaction appears to be induced, or at least considerably amplified by the presence of fungi introduced by the insect (Berryman, 1972; Christiansen and Horntvedt, 1983; Raffa and Berryman, 1983; Cook and Hain, 1986; Christiansen et al, 1987; Lieutier et al, 1988; Lieutier, 1992). The success or failure of each attack depends on the outcome of the struggle between the bark beetle and its associated fungi, and the intensity of the defence reaction at the site of attack. The defensive ab.lity of a tree can be represented by the attack density threshold above which the tree is no longer able to resist. Since the production of induced resin is costly in terms of energy (Croteau and Loomis, 1975) this threshold should be higher the lower the energy mobilized in each reaction. The attack density threshold appears to depend on the vigor of the tree at the time of attack (Berrymn, 1978; Waring and Pitman, 1983; Mulock and Christiansen, 1986). Tree vigor is conditioned by several factors among which climatic factors are probably determining. A number of authors have reported that the worst bark beetle damage in conifer forests are often preceded by a major period of drought (Christiansen et al, 1987; Mattson and Haack, 1987; and references therein). Thus, there is probably a relationship between the water status of a tree, the attack density threshold, and the characteristics of the induced reaction. The present paper investigates the relationships between tree water status and the characteristics of the induced reaction.
MATERIALS AND METHODS

\section{Water stress treatments}

Fourteen 6-yr-old (2.20 $\mathrm{m}$ high) Scots pines grown in pots were divided into 2 groups and watered with a drop-by-drop system. Group A (control) received $\approx 20$ I of water per wk per tree, while group $B$ was subjected to water stress beginning on May 12, Julian d 133. After this date, the group $B$ trees received 3 I of water per wk per tree until June 16, Julian d 168, 9 I from June 16-July 3, Julian d 185, 6 I from July 3August 7 , Julian d 220, and again 3 I per wk per tree thereafter.

\section{Tree water status}

Predawn leaf water potential $\left(\psi_{w D}\right)$ was measured with the pressure chamber technique (Scholander et al, 1965). The measurements were carried out on 2 pairs of needles per tree from the current year shoots. Needles were collected between 4:30 and 5:30 am GMT every 10-20 d. Stress intensity at a given date of inoculation was evaluated as the average $\left(\psi_{\mathrm{wD}}\right)$ of measurements made on the same tree between $6 \mathrm{~d}$ prior to and $16 \mathrm{~d}$ after inoculation.

\section{Tree defence reactions}

The reactions were induced with artificial inoculations of Ophiostoma brunneo-ciliatum (Math$\mathrm{K})$ or Leptographium wingfieldii (Morelet), 2 Ascomycete fungi previously isolated from the pine bark beetle Ips sexdentatus Boern and Tomicus piniperda $L$ respectively (Lieutier et al, 1989). These fungi had been cultivated and purified as monospore cultures on a malt-agar medium. Five-mm diameter agar implants from 3-wk-old cultures were introduced into the trees at the cambium level accoring to a technique derived from Wright (1933) and which has been previously described (Lieutier et al, 1989). One inoculation was performed per tree on May 22 (Julian d 143), July 11 (Julian d 193), 1989 with O brunneo-ciliatum, August 16 (Julian d 229), and September 211989 (Julian d 265) with $L$ wingfieldii. Two or 3 wk after inoculation, the bark around 
the inoculation points was pulled away to expose the reaction zone of the phloem. This reaction zone was then measured (length) and cut into samples which were immediately placed into dry ice under a nitrogen atmosphere. These samples were kept at $-35^{\circ} \mathrm{C}$ until analysis for total resin content. Samples of non-inoculated phloem, as well as sapwood and shoot axes (phloem and xylem) of new growth were taken on December 21, 1988, March 20,1989, and on the days of inoculation; they were frozen, and stored in the laboratory at $-35^{\circ} \mathrm{C}$ before analysis for their carbohydrate content. Noninoculated phloem and sapwood were sampled near the inoculation point, and the shoots at the end of lateral branches directly above the inoculation point.

\section{Analyses}

The resin content in the induced reaction zones was measured according to a previously described method (Lieutier et al, 1989). The results were expressed as the total quantity of resin present in fresh whole reaction zones. Carbohydrates, separated into a soluble and hydrolysable fraction, were measured and expressed in terms of glucose equivalents by the anthrone colorimetric method used by Mokrash (1954) and modified by Sauvard (1988).

\section{RESULTS}

\section{Water status of trees}

Watering of control trees kept their predawn leaf water potential at relative stable levels between -0.3 and $-0.6 \mathrm{MPa}$ during the whole experiment (fig 1). In stressed trees, 2 phases can be distinguished. The first coincides with the first inoculations and was characterized by a strong water deficit $\left(\psi_{\mathrm{wD}}\right.$ down to $\left.-2.1 \mathrm{MPa}\right)$. The second, where $\psi_{\mathrm{wD}}$ was between -0.55 and $-1.2 \mathrm{MPa}$, began at Julian d 182 and continued until the end of the expriment.

\section{Defence reactions}

The defence reaction zone of the stressed trees was only once significantly shorter than that of the control trees (May; $15 \pm 4.7$ $\mathrm{mm}$ for the control and $5.6 \pm 3.0 \mathrm{~mm}$ for the stressed trees). Total quantity of resin in the defence reaction zone never differed significantly between the 2 categories of trees.

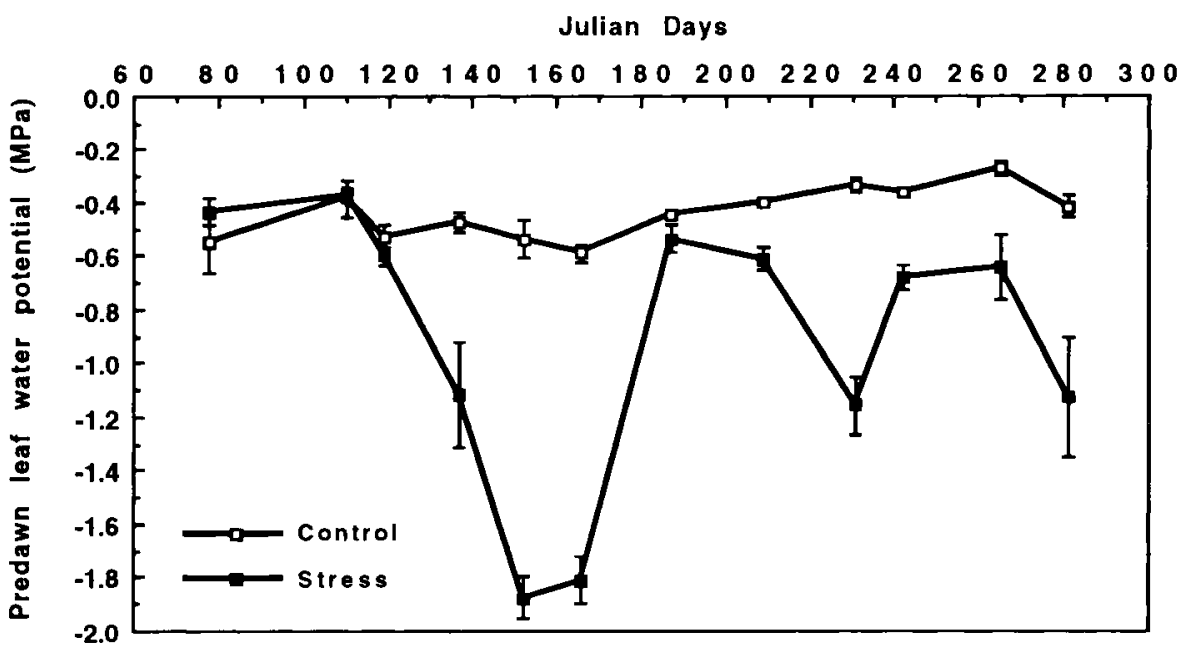

Fig 1. Time course of predawn leaf water potential $\left(\psi_{w D}\right)$. Bars indicate the standard error. 
However, the correlations between $\left|\psi_{\mathrm{wD}}\right|$ and the characteristics of the defence reactions (length and resin quantity) were constantly negative (table I). Three of them ( 2 for the length and 1 for resin quantity) differed significantly $(P \leq 0.05)$ from zero and another (concerning resin quantity) was almost significant $(P=0.058)$.

\section{Carbohydrate reserves (table II)}

After statistical analyses, phloem, xylem and shoots showed no significant differences between the carbohydrate (soluble

Table I. Correlations between predawn leaf water potential $\left|\psi_{w D}\right|$ and the characteristics of the defence reaction (length and total resin quantity), for the different periods of inoculation.

\begin{tabular}{lllll}
\hline & $\begin{array}{l}\text { May } \\
\text { Obc }\end{array}$ & $\begin{array}{l}\text { July } \\
\text { Obc }\end{array}$ & $\begin{array}{l}\text { August } \\
\text { Lw }\end{array}$ & $\begin{array}{l}\text { Sept } \\
\text { Lw }\end{array}$ \\
\hline Length & $-0.73^{* \star}$ & -0.25 & -0.16 & $-0.68^{* *}$ \\
$\begin{array}{l}\text { Resin } \\
\text { quantity }\end{array}-0.38$ & $-0.52+$ & -0.19 & $-0.64^{*}$ \\
\hline
\end{tabular}

Correlation coefficient significantly different from zero

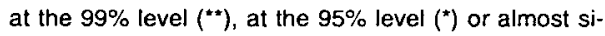
gnificantly different from zero $(t)$. Fungus inoculated: $O b c=$ Ophiostoma brunneo-ciliatum; $L w=$ Leptographium wingfieldii. or hydrolysable) content of stressed trees and that of control trees. Otherwise, the carbohydrate content of each compartment did not vary very much over time.

\section{DISCUSSION}

Since the trees recovered from all inoculations it may be hypothesized that the length of the reaction zone was proportional to the duration of the struggle between the tree and its aggressor, and that total quantity of induced resin included in the reaction zone was proportional to the quantity of energy invested by the tree in its defence. Under these conditions, our results suggest that the aggressors were arrested more rapidly and that the quantity of energy invested for that purpose was lower in the stressed trees.

We cannot a priori discard a direct effect of stress on the fungus. However, phytopathogenic fungi are generally more tolerant than plants to water deficits (Pinon, 1986; and references therein). According to Cook and Papendick (1972; in Pinon, 1986), fungal growth is still possible for water potentials as low as -3 to $-5 \mathrm{MPa}$. Sometimes, water stress can even provoke stimulation of that growth, as observed by Bagga and Smally (1967; in Pinon, 1986) for the aspen canker in in vitro

Table II. Mean quantity of soluble (Sol) and hydrolysable (Hydr) carbohydrates in the shoots, phloem and xylem of the experimental trees.

\begin{tabular}{|c|c|c|c|c|c|c|}
\hline & $\begin{array}{l}\text { Shoots } \\
\text { Sol }\end{array}$ & $\begin{array}{l}\text { Shoots } \\
\text { Hydr }\end{array}$ & $\begin{array}{l}\text { Phloem } \\
\text { Sol }\end{array}$ & $\begin{array}{l}\text { Phloem } \\
\text { Hydr }\end{array}$ & $\begin{array}{l}\text { Xylem } \\
\text { Sol }\end{array}$ & $\begin{array}{l}\text { Xylem } \\
\text { Hydr }\end{array}$ \\
\hline C & $8.4 \pm 1.1$ & $4.2 \pm 0.3$ & $13.1 \pm 1.3$ & $8.4 \pm 1.6$ & $2.0 \pm 0.4$ & $3.8 \pm 0.5$ \\
\hline$S$ & $10.6 \pm 1.9$ & $4.1 \pm 0.2$ & $15.0 \pm 1.1$ & $7.3 \pm 1.0$ & $2.4 \pm 0.4$ & $3.7 \pm 0.4$ \\
\hline
\end{tabular}

Value are expressed as $\%$ of dry weight. Confidence intervals are given at the $95 \%$ level. Differences between stressed trees and control trees were never significant. $\mathrm{C}=$ control trees; $\mathrm{S}=$ stressed trees. 
cultures. Under these conditions it seems unlikely that the decrease in the induced reaction in our experiment was due to a decrease in fungal vitality.

Some data on response regarding the relationships between water stress and the induced defence reaction have been obtained. A constant negative correlation was observed between the characteristics of the defence reaction and the predawn leaf water potential. Thus, it seemed that when water stress increased, both reaction length and quantity of induced resin in that reaction decreased. The decrease in the amount of induced resin is in agreement with the decrease observed by Lorio (1986) for constitutive resin in Pinus taeda during a period of severe drought. It is also in agreement with the findings of Paine and Stephen (1987) who noticed for the same species a less important induced reaction in the dominated trees than in the dominant trees. Stephen et al (1983) claimed that an important defence reaction would correspond to trees resistant to bark beetle attacks. In Norway spruce, Christiansen et al (1987) observed that marked reactions could develop in weak trees close to death. This observation seems to be in opposition to our present results; however the situation described by these authors was obtained with an inoculation density above the lethal threshold; in these conditions, the fungus extended to the whole phloem. It was very different from our situation with isolated inoculations which were always contained by the tree response. Nevertheless, Lorio (personal communication) observed an increase in constitutive resins during a limited period of drought, and Lieutier and Ferrell (1988) reported an increase of induced reaction in Scots pine when tree growth efficiency decreased.

Our results did not demonstrate any modification in the amount of stored carbohydrates in the shoots, phloem and xylem in response to water stress (table II). Possibly a longer or a more intense water stress would have been necessary to induce such modifications. Indeed, Grieu et al (1988) reported an increase of the soluble carbohydrates in Douglas fir needles for strong water stress $\left(\psi_{\mathrm{wD}}=-1.6 \mathrm{MPa}\right)$. However, these authors observed only weak variations of these compounds in the needles and in the roots of the same tree and in those of Pseudotsuga macrocarpa and Cedrus atlantica, with a leaf predawn water potential below $-2 \mathrm{MPa}$. It is therefore difficult to consider the observed variations in the tree defence reactions to be a consequence of variation of stored carbohydrates.

These conclusions agree with the results of Christiansen and Ericsson (1986) who reported that the level of stored starch was not correlated with Picea abies resistance to infection by Ophiostoma polonicum. Owing to the fact that resin synthesis is costly for the tree (Croteau and Loomis, 1975), Christiansen and Ericsson (1986) have suggested that the flow of assimilates might be the main source of energy for the development of the defence reactions. Stored starch might thus be a complementary source of energy when the current flow is not sufficient. Otherwise, the study of resin biosynthesis in Pinus pinaster (Bernard-Dagan, 1988) suggested that the ascending flux of soluble carbohydrates from roots might also be an important energy source for the induced reactions. According to the same authors, the possible catabolism of the heartwood resin might locally participate in the defence mechanisms at the beginning of the annual growth activity.

\section{ACKNOWLEDGMENTS}

The authors are grateful to $E$ Christiansen (NISK, Norway) and E Dreyer (INRA, France) 
for their comments on the manuscript. They also thank J Garcia and P Romary for their technical help.

\section{REFERENCES}

Bernard-Dagan C (1988) Les substances de réserve du Pin maritime: rôle éventuel des métabolites secondaires. Bull Soc Bot Fr ACtual Bot 135, 25-40

Berryman AA (1972) Resistance of conifers to invasion by bark beetle-fungus associations. Bio-Science 22, 599-601

Berryman AA (1978) A synoptic model of the Lodgepole pine/Mountain pine beetle interaction and its potential application in forest management. In: Theory and Practice of Mountain Pine Beetle Managment in Lodgepole Pine Forests (Berryman AA, Amman $\mathrm{GD}$, Stark RW, Kibbee DL, eds) College For Res, Univ Idaho, Moscow, ID, 98-105

Christiansen E, Horntvedt R (1983) Combined Ips/Ceratocystis attack on Norway spruce, and defensive mechanisms of the trees. $Z$ Angew Entomol 96, 110-118

Christiansen E, Ericsson A (1986) Starch reserves in Picea abies in relation to defence reaction against a bark beetle transmitted blue-stain fungus, Ceratocystis polonica. Can J For Res 16, 78-83

Christiansen $E$, Waring $\mathrm{RH}$, Berryman $\mathrm{AA}$ (1987) Resistance of conifers to bark beetle attack: searching for general relationships. For Ezol Manage 22, 89-106

Cook SP, Hain FP (1986) Defensive mechanisms of Loblolly and Shortleaf pine against attack by southern pine beetle, Dendroctonus frontalis Zimmerman, and its fungal associate, Ceratocystis minor (Hedgecock) Hunt. J Chem Ecol 12, 1397-1406

Croteau R, Loomis WD (1975) Biosynthesis and metabolism of monoterpenes. Int Flavours Food Addit 6, 292-296

Grieu P, Aussenac G, Larher F (1988) Sécheresse édaphique et concentrations en quelques solutés organiques des tissus foliaires et racinaires de trois espèces de conifères: Cedrus atlantica Manetti, Pseudotsuga macrocarpa (Torr) Mayr, Pseudotsuga menziesii (Mirb) Franco. Ann Sci For 45, 311-322
Lieutier F (1992) Induced defence reaction of conifers to bark beetles and their associated Ophiostoma. In: Ceratocystis and Ophiostoma: Toxonomy, Biology and Pathogenicity (Wingfield MJ, Seifert KA, Webber JF, eds) Am Phytopathol Soc Press, 206-215

Lieutier F, Ferrell GT (1988) Relationships between indexes of tree vigour and the induced defense reaction of Scots pine to a fungus associated with ips sexdentatus (Coleoptera: Scolytidae). In: Integrated Control of Scolytid Bark Beetles (Payne TL, Saarenmaa H, eds) Virginia Polytechnic Inst and State Univ, Blacksburg, VI, 163-178

Lieutier F, Yart A, Garcia J, Poupinel B, Levieux J (1988) Do fungi influence the establishment of bark beetles in Scots pine? in: Mechanisms of Woody Plant Defenses Against Insects; Search for Pattem (Mattson WJ, Levieux J, BernardDagan $C$, eds) Springer Verlag, 321-331

Lieutier F, Yart A, Garcia J, Ham MC, Morelet $M$, Levieux J (1989) Champignons phytopathogènes associés à deux coléoptères Scolytidae du Pin sylvestre (Pinus sylvestris L) et étude préliminaire de leur agressivité envers I'hôte. Ann Sci For 46, 201-216

Lorio PL Jr (1986) Growth-differentiation balance: a basis for understanding Southern pine beetle-tree interaction. For Ecol Manage 14, 259-273

Mattson WJ, Haack RA (1987) The role of drought in outbreaks of plant-eating insects. Bio Science 37, 110-118

Mokrash LC (1954) Analysis of hexose phosphates and sugar mixtures with the anthrone reagent. J Biol Chem 208, 55-59

Mulock P, Christiansen E (1986) The threshold of successful attack by Ips typographus on Picea abies: a field experiment. For Ecol Manage 14, 125-132

Paine TD, Stephen FM (1987) Influence of tree stress and site quality on the induced defense system of Loblolly pine. Can J For Res $17,569-571$

Pinon $\mathrm{J}$ (1986) Les maladies de faiblesse en plantation. Rev For Fr 38, 324-330

Raffa KF, Berryman AA (1983) Physiological aspects of Lodgepole pine wound responses to a fungal symbiont of the mountain pine beetle, Dendroctonus ponderosae (Coleoptera: Scolytidae). Can Entomol 115, 723-731

Sauvard D (1988) Capacité de multiplication de Tomicus piniperda L (Coleoptera: Scolytidae) 
selon la densité d'attaque et diverses caractéristiques de l'arbre. Thèse Doctorat, Université d'Orléans La Source, $130 p$

Scholander PF, Hammel HT, Bradstreet ED, Hemmingsen EA (1965) Sap pressure in vascular plants. Science 148, 339-346

Stephen FM, Paine TD, Lih MP (1983) Understanding bark beetle/host interactions: a means for improving decision strategies. $Z$ Ang Entomol 96, 257-265

Waring RH, Pitman GB (1983) Physiological stress in Lodgepole pine as a precursor for Mountain pine beetle attack. $Z$ Ang Entomol 96, 265-270

Wright E (1933) A cork-borer method for inoculating trees. Phytopathology 23, 487-488 